\title{
EFFECT OF DIFFERENT FEEDING LEVELS ON GROWTH PERFORMANCE AND POND PRODUCTIVITY OF THE NILE TILAPIA (ORECHROMIS NILOTICUS), THE GREY MULLET (MUGIL CEPHALUS) AND THE COMMON CARP (CYPRINUS CARPIO) STOCKED AT HIGHER RATES
}

\section{Nabil F. Abdel-hakim ${ }^{1}$; Mohammed S. Lashen ${ }^{1}$; Mohammed N. Bakeer ${ }^{2}$ and Abdel Rahman A. Khattaby ${ }^{2}$ \\ 1- Fac. Agric., Al-Azhar Univ. \\ 2- Central Laboratory for Aquaculture Research at Abassa, Sharkia Governorate, Egypt.}

Key words : feeding levels, Nile tilapia, Mullet , common carp , earthen pond, polyculture.

\begin{abstract}
7 his study was carried out to investigate the growth performance of Nile tilapia , Grey mullet and Common carp fish species stocked at higher rates and reared in earthen ponds as well as pond productivity as affected with different feeding levels. Eight earthen ponds were used; each of a total area of $8000 \mathrm{~m}^{2}$ represented four feeding levels (1.5 , 2.5 , 3.5 and $4.5 \%$ of total biomass of fish) with two replicates for each feeding level . Fish species were stocked in each pond at densities of 48000,9000 and 3000 with an average initial weight of 25, 8 and $5 \mathrm{~g}$ for tilapia , mullet and carp species, respectively. The experiment was expanded for 8 months after start. Results obtained are summarized in the following:

1- Final weight, weight gain, daily gain and SGR of the three tested species increased significantly with each increase in feeding levels tested. 2- Total Fish production of the three tested species increased in almost linear manner with each increase in feeding levels from 1.5 to 2.5 ; 3.5 or $4.5 \%$ of the fish biomass.

3-The highest net returns were obtained by the feeding rate $2.5 \%$ followed in a decreasing order by $1.5 ; 3.5$ and $4.5 \%$ feeding rates respectively.
\end{abstract}


Based on the obtained results it is recommeneded a feeding level of 2.5 $\%$ for tilapia , mullet and carp cultured together at higher rate in earthen ponds without supplemental aeration.

\section{INTRODUCTION}

Mono - sex Nile tilapia , Grey mullet and Common carp response very good to earthen pond polyculture system , however information on intensification and temporal variations in fish food intake are very limited. This information might help in the designing of feeding regimes for fish in aquaculture . Supplementary feed constitutes about $60 \%$ of total fish production costs (NRC,1983; Sadek, 2000; FAO,2002).

Determining the optimum pattern of feed added to fish ponds is one of the most important tasks in pond management. Therefore, some concern should be paid to reduce this expenne by feeding the correct amount at the right time to insure maximum efficiency. Meanwhile, realization of the optimum feeding regime for cultured fish would help to reduce feed wastes, costs and maximizing feed conversion efficiency (Abdel Hakim et al., 2004 Bakeer and Tharwat 2006).

The objectives of this study were to determine the effects of feeding levels on the following parameters: growth performance, fish production and economical efficiency of Nile tilapia, Grey mullet and Common carp stocked at higher rates and cultured in earthen ponds under polyculture system .

\section{MATERIALS AND METHODS \\ Experimental ponds}

The present study was carried out in eight earthen ponds belonging to a fish farm at EL-Mahmoudiya, Behira Governorate , Egypt . Total water area of each pond was $8000 \mathrm{~m}^{2}$ with a water depth of one meter . Before the experimental start, all ponds were drained completely and were exposed to sunray for 15 days till complete dryness. Ponds were refilled with fresh water coming from Idiko drainage canal through a branch to the fish farm . All experimental ponds were equipped with screens at the water in and out lets to prevent the entrance of wild fish and escaping of the experimental fish . Ponds did not receive any supplemental aeration. Water level was maintained at one-meter level throughout the whole experimental period from $15^{\text {th }}$ April to $15^{\text {th }}$ December 2005. Pond waters were exchanged at a rate of $5 \%$ at the start and at $25 \%$ levels during the advanced stages of fish growth. 


\section{Feeding levels.}

Eight experimental ponds were used, representing four feeding levels ( $1.5 ; 2.5 ; 3.5$ and $4.5 \%$ of total biomass of fish ) and each level was tested in two replicates (duplicates ). Fish were fed on a commercial diet $(25 \% \mathrm{CP}$ and $4580 \mathrm{Kcal} / \mathrm{Kg}$ diet) and ponds were fertilized with organic fertilizers ( Chicken manure ) at a rate of $100 \mathrm{~kg} /$ pond/month. Fish were fed the commercial pelleted diet by hand feeding twice daily at 10 a.m. and 2 p.m. The composition of the diet used was $4 \%$ fish meal (70\%) ; 43\% Soybean meal (44 \%) ; $45 \%$ yellow corn (8.5 \%); 6\% vege table oil ; $1 \%$ vitamin mixture and $1 \%$ mineral premix . The chemical composition of the diet used was $7.25 \%$ moisture , $24.7 \%$ crude protein , $9.70 \%$ crude fat , $4.20 \%$ crude fiber and 4.20 ash , while that of chicken manure was $8.9 \%$ moisture , $18.9 \%$ crude protein , $2.9 \%$ crude fat , 32 $\%$ ash , $12 \%$ crude fiber , nitrogen 1.7 , potassium 1.0 and phosphorus $2.0 \%$. The diameter of the pelleted diet was $2 \mathrm{~mm}$ and the diet was purchased from Zo_Control Fad Mill Company, 6 October City, while chicken manure was obtained from chicken farm closed to the experimental farm.

\section{Experimental fish}

Every experimental pond was stocked with 48000 fingerlings of mono - sex Nile tilapia (Oreochromis niloticus) with an average initial weights averaging between 25.20 to $25.71 \mathrm{~g}$, 9000 grey mullet fingerlings (Mugil cephalus ) with initial weight 8.29 to $8.80 \mathrm{~g}$ and 3000 common carp ( Cyprinus carpio) with initial weight ranging from 5.31 to $5.81 \mathrm{~g}$.

\section{Records maintained :}

Individual body weight to the nearest $0.1 \mathrm{~g}$ were measured at the start of the experiment in samples of 150 fish from each species and repeated every four weeks periods throughout the experimental period . Fish samples were withdrawn from the experimental ponds by sinning and fish were collected in a tank containing water from the experimental ponds and returned back to ponds after measuring their weights and lengths . Proximate analysis of whole fish bodies was carried out at the end of the experimental period in 15 specimens of each species . Analysis of whole fish bodies as well as the experimental diets were performed according to the methods described by A.O.A.C (1990). Parameters of daily gain and specific growth rate (SGR) and feed conversion ratio (FCR) were calculated according to the following equations : 
Daily gain $\mathrm{g} /$ day $=\frac{\mathrm{W}_{2}-\mathrm{W}_{1}}{\mathrm{t}}$

SGR $=$ Ln weight $2-$ Ln weight 1 X $100 /$ period days.

Where : $\mathrm{Ln}=$ the natural log.

$\mathrm{W}_{1}=$ Initial fish weight in grams.

$\mathrm{W}_{2}=$ Final fish weight in grams .

$\mathrm{T}=$ Period in days.

FCR = Feed intake $(\mathrm{g}) /$ Weight gain $(\mathrm{g})$

\section{Statistical Analysis}

Statistical evaluation of results was carried out according to Harvey Computer Program (1990). Duncan's Multiple Range test was applied to detect the significance of difference of various parameters among the treatments (Duncan , 1955).

\section{RESULTS AND DISCUSSION}

\section{Growth performance}

Results of Table (1) show that the initial weight of tilapia, mullet and common carp was ranged between 24.8 to $25.28 \mathrm{~g}$; 7.8 to $8.30 \mathrm{~g}$ and 4.8 to $5.31 \mathrm{~g}$, respectively, with insignificant differences in initial weight within each fish species among the experimental groups at the begining of study. Final weights of the studied species increased in a significant order $(\mathrm{P}<0.05)$ with each increase in feeding levels tested. The weight gain, daily gain and specific growth rate behaved similers to the body weight, where both increased in a linear significant $(\mathrm{p}<0.05)$ pattern with each increase in feeding levels. In general, growth parameters (final weight, weight gain , daily gain and SGR) of the three tested species increased significantly with each increase in feeding levels tested. These results are in accordance with the findings of Wu-Goanyun (1992), Abdel-Hakim et al. (2000,2000 2001 and 2001 $\left.{ }^{\mathrm{a}}\right)$, Yaseer (2005) and Hassan et al. (2006), who found that tilapia cultured with mullet and carp had significantly $(\mathrm{p}<$ 0.05 ) superior final weights when fed at higher rates using 28 or $32 \%$ dietary protein diets. Results presented in Table (2) illusrate the effect of feeding levels on feed conversion ratio (FCR) of polyculture system (tilapia, mullet and carp). The results indicate that FCR were $1.43 ; 1.41$; 1.71 and 1.99 for treatments $1.5 \%$; $2.5 \%$; 3.5\% and $4.5 \%$, respectively. The differences in FCR had attributed to the differences in feed intake. Thus, the feeding levels tested differ in their quantity and consequently the FCR was affected. These results indicate that feeding of the Nile 
tilapia in polyculture system with mullet and common carp at earthen ponds on feeding level of 2.5\% resulted in best FCR record. These results are in complete agreement with results of Wu_Goangyum (1992) Abdel_Hakim et al. (2000) and Yasser (2005) who studied the high yield of polyculture of mullet and carps.

\section{Survival rate}

Result presented in Table (1) illustrate the effect of feeding levels on survival rates. The results indicate that survival rate during the whole experimental period for tilapia, mullet and common carp had ranged between 65.43 to $78.11 \%$; 55.12 to $60.90 \%$ and 82.13 to $88.33 \%$ respectively with significant differences in survival rate within each fish species among the experimental groups, which indicate that feeding levels had remarkable effects on tilapia , mullet and common carp survival . These results are not in accordance with the findings of Abdel Hakim et al. (2001), who reported that neither level fed nor stocking density of fish had an influence on survival rates of fish species studied. Moreever, Bakeer (2006) reported that survival rate was decreased for fish fed on higher feeding rate (6-8 \%). However, no more mortality was observed for fish fed on lower feeding levels (2-4\%).

\section{Effect on total fish production}

Results of Table (3) show that the total fish production ( Kg/feedan ) were found to be 3718.63; 3948.54; 4222.21 and 4536.02 Kg for feeding levels 1.5; 2.5; 3.5 and $4.5 \%$, respectively. These results indicate that the total fish production / feddan increased with each increase in feeding rate tested. The total pond productivity calculated as percentages of the lowest one (1.5\% feeding rate, $100 \%)$ were 106.18 ; 113.54 and $121.98 \%$ for feeding rates 2.5 ; 3.5 and $4.5 \%$ respectively. The contribution of tilapia in the total harvest had ranged between 72.82 to $75.61 \%$; for mullet between 10.46 and $11.20 \%$ and for common carp between 13.93 to $18.28 \%$. These results are in agreement with the findings of Abdel-Hakim et al. (2000); Bakeer (2006); Hassan et al.(2006) Abd-Ellal (1999), Soltan et al. (1999), Green et al. (1995), ElEbiary (1994) and Essa et al.(1989) who reported similar results.

\section{Economic evaluation}

Results of costs analysis including costs of fish fingerlings, feed costs, costs of fertilization, labor, pumbs and solar for treatments applied are shown in Table (4). Results revealed that costs of fish fingerlings, fertilization , labor ; pumps and solar are similar in the treatments applied Table (4), however the feed costs differed, according to feeding level and 
were the lowest for the feeding level 1.5 (9088.24 L.E.) and increased to 9505.77 ; 12340.85 and 15383.74 L.E. for $2.5 \%$; 3.5\% and $4.5 \%$ feeding levels, respectively. Total costs per feddan increased from 17113.34 LE to 16530.87 LE ; 20365.95 LE and 23408.44 for treatments 1.5\% 2.5\% ; $3.5 \%$ and $4.5 \%$, respectively. The differences in total costs had attributed to the differences in feed costs. Thus, the feeding levels tested differ in their quantity and consequently the price of feeding. Total returns in LE/feedan for feeding levels $1.5 \%$, 2.5\%; 3.5\% and 4.5\% were 26030.41; 27639.78 ; 29555.47 and 31752.14 L.E. , respectively (Table 4). Net returns per feddan in L.E. for feeding level $1.5 \%$; $2.5 \%$; $3.5 \%$ and $4.5 \%$ were 8927.07 ; 10108.91 ; 9189.52 and 8343.3 L.E. and its percentage to the lowest net returns feeding levels (4.5\%) 100 were found to be $110.14 \% ; 121.16 \%$ and $106.99 \%$ for feeding level $3.5 \% ; 2.5 \%$ and $1.5 \%$, respectively. These results indicate that feeding of the Nile tilapia in polyculture with mullet and common carp in earthen ponds at feeding level of $2.5 \%$ resulted in best economic efficiency. These results are in complete agreement with results of Green and El Nagdy (1995), AbdelHakim et al.(2000), working with tilapia, eel and mullet in polyculture system..

\section{REFERENCES}

Abdel -Hakim , N. F.; Bakeer, M. N. and Soltan, M. A. (2001 $\left.{ }^{\mathrm{a}}\right)$. Effect of protein level and stocking density on growth performance of Nile tilapia ( O.niloticus) cultured in tanks. Egyptian J. Nutrition and Feeds, 4:763-780.

Abdel -Hakim , N. F.; Bakeer, M. N. and Soltan, M. A. (2001 $\left.{ }^{\mathrm{b}}\right)$. Effect of two manuring systems on water quality and plankton communities in fishponds .Conference of Social and Agric. Develop. of Sinai pp:147-158.

Abdel-Hakim, N. F.; Bakeer, M. N. and Soltan, M. A. (2000). Growth performance of eel (Anguilla anguilla), Nile tilapia (Oreochromis niloticus) and grey mullet (Mugil cephalus) cultured in cages under two feeding systems. Proc. $3^{\text {rd }}$ All Africa Conf. Anim. Agric. \& $11^{\text {th }}$ Conf. Egyptian Soc. Anim. Prod., Alexandria, Egypt, 6-9 November 2000 : 329-335. 
Abdel-Hakim, N. F. ; Ammar, A. A. and Bakeer, M. N. (2004) .Effect of stocking density and feeding systems on growth perfprmance of Nile tilapia (O. niloticus) reared in concrete tanks. J.Egypt. Acad. Soc. Environ. Develop. (BAquaculture), 5 (2):87-105.

Abdelhamid, A. M.(2003) Scientific Fundamentals for Fish Production and Rearing Mansoura Univ. Press, $2^{\text {nd }}$ Ed., Deposit No.: $15733 / 2003$.

Abdel-Maksout, A. M. S. (2000). Response og grey mullet (Mugil cephalus L.), Cultured in earthen ponds, to diets of varying protein levels, Egypt. J. Anim. Prod., 37 (1): 57-66.

Afifi, E. A.; Fatma A. H.; Abdel-Hakim, N. F. and Abdella, M. M. (1996). Effect of mullet stocking rate on sam productive trais in fish. Egypt. J. Agric. Res., 74(2).

Anyanwu, P. E. and Awa. J. N. (1988). Polyculture trial of mullets (M. spp.), Tilapia sp., Hemichromis sp. and Elops sp. TechPap-Niger-Tnst_Oceanogr-Mar-Res Victoria-Island,-LgosNigeria NIOMR $1988.33-15$.

AOAC Association of Official Analysis Chemists.(1990). Official Methods of Analysis, $15^{\text {th }}$ ed., pp 1298,Virginia.

Bakeer, M. N.(2006).Studies on fish production: Growth and Survival of Eel (Angulla angulla) Fingerings fed at different intake levels. Annals of Agric. Sci., Moshtohor (under puplish).

Brune, D.E.; Schwartz, G. Eversole, A.G. Collier, J.A. and Schwedler, T.E. (2003). Intensification of pond aquaculture and high rate photosynthetic systems. Aquaculture Engineering, 28: 65-86.

Boyd, C. E. (1979): Water quality in warm water fish ponds. Ed- Claude E. Boyd Third printing1984. Pub. Auburn Univ. Agri. Exp. Staio. AID/Dsan-G.G.0039. 359 pp.

Boyd, C. E. (1990): Water quality in ponds for Aquaculture Alabama Agriculture Experiment Station Auburn University, 
Alabama. 462pp.

Boyd, C. E. and Tucker C. S. (1998). Pond Aquaculture Water Quality Management klwer, Boston.

Duncan, D. B. (1955). Multiple range and multiple F test. Biometrics 77:1-42.

El-Ebiary, E. H. (1994). Studies on fish production : Relationship between nutrition and reproduction of Tilapia sp. ,Ph.D. Thesis Agric. Sci., Alexandria Univ.

El Dakar, Y. Ashraf, (1999)Effect of different feed levels on performance of Rabbit fish , Signus rivulatus , fingerlings. Egypt. J . Aquat. Biol \& fish , 3 (4):35-5b.

El-Sayed, A.;Mostafa, K. A.; Al-Mohamadi , J. S. and Kayid, M. (1993) Intensive culture of rabbit fish in Qatar: Effedts of stocking density and feeding levels on growth rates and feed utilization of Sigaus canliculatus. Proceedings of Aquaculture Symposium, technology and Invetment opportunities . 11-14 April 1993. Riyadh , Saudi Arabia, pp.109-117.

E.I.F.A.C., (1993) .Water quality criteria for European fresh water fish Report on ammonia and inland fisheries .European .Inland Fisheries Advisory Commission .Water Res.,7: 10111022.

Essa, M. A. ; EI-Sherif, Z. M. ; AbouI-Ezz, S. and Abdel-Moati, A.R. (1989). Affect of water quality, food availability and of some economical fish species grown under polyculture system. Bull. Nat. Ins. Oceanogr. And Fish., Egypt, 15(1):125-134.

FAO (2002).Fishery statistics 2000, Capture production, FAO,Rome.

Gannam , A. and Phillips, J. ( 1993) .Effect of temperature on growth of O.niloticus , p 136-143 .In Egna H.; M.Mc Namara , J. Bowman , and N,Astin (eds. ). $10^{\text {th }}$ Annual Administrative Report.Pond Dynamics / Aquaculture CRSP., Oregon 
State Univ., Corvallis .Oregon .

Green, B. W. and El Nagdy, Z. (1995). Evaluation of Nile tilapia production systems in Egypt. Thirteenth Administrative Report. Pond Dynamics/Aquaculture. Collaborative Research Support Program, Office of International Research and development, Oregan State University, Corvallis Oregon, USA.1-12.

Harvey, W. R. (1990).User's guide for LSMLMW. Mixed model leastsquares and Maximum likelihood computer prog. Ohio state university. Columbus, USA. Hickling, C.F. (1970). A comparison to the natural history of the English grey mullets ( Pisces, Mugilidae ). J. Mar Biol Ass. U.k. 50: 609-633.

Hassan , A. A; Mahmoud, A. A. and Sayed, S.H. (2006).Effect of method and rates of feeding on the growth performance and feed utilization of Mono sex Tilapia nilotica (O.niloticus L.) in semi-intensive culture system J. Agric. Sci. Mansura Unv., 31(5):2743-2753 .

Lin , C. K. and Yi, Y. (2003). Minimizing environmental impacts of freshwater aquaculture and reuse of pond effluents and mud. Aquaculture, 226:57-68.

Nguenga. D. ; Breine. 1. J.; Sulem Yong, S. ; Teugels, G. G. and Ollevier, F. (1997). Effect of animal manure and chemical fertilizer on growth and survival of tilapia comeronsis Holly in Cameroon. Aquacult. Res., 28:231-234.

NRC (1983). Nutrient requirements of Warm water Fishes Shellfishes. National Research Council, National Academy Press. Washington DC., USA. 102pp.

Omer E.(1986).Studies on Tilapia feeding .1-effect of different feeding levels on growth performance and feeding utilization .J.Anim Prod., 26 (2):171-183. 
Sadek, S. (2000). Aquaculture in Egypt: Past evaluation, present status and priorities for research to secure a sustainable development. Proc. Inter. Conf. AQUA 2000, Nice, France, May 2 - 6, 620 pp.

Shiau, S. Y. (2002). Tilapia, Oreochromis spp. In: Fish Nutrition (eds) C.D. Webster and C. Lirn. CAB International, pp. 273292.

Soltan, M. A., Abdel-Hakim, N. F. and Bakeer, M.N. (1999), Effect of stocking rate, organic fertilization and supplementary feed on growth performance, carcass and chemical analysis of Nile tilapia , O. niloticus. Egyptian J.Nutrition and Feeds, 2(special Issue), pp. 765 -777.

Suresh, A.V. (2000). Fish feed is not cheap; A look at formulation and manufacturing of aquaculture. Proc. Inter- Conf. AQUA 2000, Nice, France, May 2 - 6, 690pp.

Wurts, W.A. (2003) .Daily pH cycle and ammonia toxicity. World Aquaculture Magazine , 34(2): 20.

Wu-Goangyun, (1992). Experiment on high yield of polyculture of mullet and carps in the pond. Shandong-Fish-Qilu-Yuye.4:37-39.

Yasser, T. A. (2005) Effect of fertilization on fish production in earthen ponds. Ph.D Thisis, Animal and Fish Production Dep., Univ. of Alexandria. 
Table (1): least square means and standard error for the effect of feeding levels on growth parameters of Nile tilapia, Mullet and common carp.

\begin{tabular}{|c|c|c|c|c|c|c|}
\hline $\begin{array}{l}\text { Feedin } \\
\text { g levels }\end{array}$ & $\begin{array}{l}\text { Initial wt } \\
\text { (g/fish) }\end{array}$ & $\begin{array}{l}\text { Final fish } \\
\text { wt (g/fish) }\end{array}$ & $\begin{array}{c}\text { Weight } \\
\text { gain g/fish }\end{array}$ & $\begin{array}{c}\text { Daily } \\
\text { gain }\end{array}$ & SGR (\%/day) & $\begin{array}{c}\text { Survival } \\
\%\end{array}$ \\
\hline \multicolumn{7}{|l|}{ Tilapia } \\
\hline $1.5 \%$ & $\begin{array}{c}25.28 \pm 0.26 \\
\mathrm{a} \\
\end{array}$ & $\begin{array}{c}150.98 \pm 1 \\
81 \mathrm{~d}\end{array}$ & $\begin{array}{c}125.70 \pm 0.0 \\
2 \mathrm{~d}\end{array}$ & $\begin{array}{c}0.52 \pm 0.0 \\
7 \mathrm{~d}\end{array}$ & $0.74 \pm 0.01 \mathrm{~d}$ & $\begin{array}{c}73.90 \pm 0.2 \\
8 \mathrm{a} \\
\end{array}$ \\
\hline $2.5 \%$ & $\begin{array}{c}24.80 \pm 0.26 \\
\mathrm{a} \\
\end{array}$ & $\begin{array}{c}162.92 \pm 1 \\
81 \mathrm{c}\end{array}$ & $\begin{array}{c}137.64 \pm 0.0 \\
2 \mathrm{c} \\
\end{array}$ & $\begin{array}{c}0.57 \pm 0.0 \\
7 \mathrm{c} \\
\end{array}$ & $0.77 \pm 0.01 \mathrm{c}$ & $\begin{array}{c}71.22 \pm 0.2 \\
8 \mathrm{~b} \\
\end{array}$ \\
\hline $3.5 \%$ & $\begin{array}{c}25.00 \pm 0.26 \\
\mathrm{a} \\
\end{array}$ & $\begin{array}{c}180.50 \pm 1 \\
81 \mathrm{~b}\end{array}$ & $\begin{array}{c}155.70 \pm 0.0 \\
2 \mathrm{~b}\end{array}$ & $\begin{array}{c}0.64 \pm 0.0 \\
7 \mathrm{~b} \\
\end{array}$ & $0.82 \pm 0.01 \mathrm{~b}$ & $\begin{array}{c}78.11 \pm 0.2 \\
8 \mathrm{c}\end{array}$ \\
\hline $4.5 \%$ & $\begin{array}{c}25.00 \pm 0.26 \\
\mathrm{a} \\
\end{array}$ & $\begin{array}{c}200.33 \pm 1 \\
81 \mathrm{a}\end{array}$ & $\begin{array}{c}175.33 \pm 0.0 \\
2 \mathrm{a} \\
\end{array}$ & $\begin{array}{c}0.73 \pm 0.0 \\
7 \mathrm{a} \\
\end{array}$ & $0.86 \pm 0.01 \mathrm{a}$ & $\begin{array}{c}65.43 \pm 0.2 \\
8 \mathrm{~d} \\
\end{array}$ \\
\hline \multicolumn{7}{|l|}{ Mullet } \\
\hline $1.5 \%$ & $\begin{array}{c}8.30 \pm 0.12 \\
\mathrm{a} \\
\end{array}$ & $\begin{array}{c}135.22 \pm 1 \\
51 \mathrm{~d}\end{array}$ & $\begin{array}{c}126.92 \pm 0.0 \\
1 \mathrm{~d} \\
\end{array}$ & $\begin{array}{c}0.52 \pm 0.0 \\
3 \mathrm{~d} \\
\end{array}$ & $1.16 \pm 0.01 \mathrm{~d}$ & $\begin{array}{c}60.90 \pm 0.3 \\
7 \mathrm{a} \\
\end{array}$ \\
\hline $2.5 \%$ & $\begin{array}{c}7.80 \pm 0.12 \\
\mathrm{a} \\
\end{array}$ & $\begin{array}{c}155.88 \pm 1 . \\
51 \mathrm{c}\end{array}$ & $\begin{array}{c}147.58 \pm 0.0 \\
1 \mathrm{c} \\
\end{array}$ & $\begin{array}{c}0.61 \pm 0.0 \\
3 \mathrm{c} \\
\end{array}$ & $1.22 \pm 0.01 \mathrm{c}$ & $\begin{array}{c}58.11 \pm 0.3 \\
7 \mathrm{~b} \\
\end{array}$ \\
\hline $3.5 \%$ & $\begin{array}{c}8.10 \pm 0.12 \\
\mathrm{a} \\
\end{array}$ & $\begin{array}{c}175.23 \pm 1 \\
51 \mathrm{~b} \\
\end{array}$ & $\begin{array}{c}167.43 \pm 0.0 \\
1 \mathrm{~b} \\
\end{array}$ & $\begin{array}{c}0.69 \pm 0.0 \\
3 \mathrm{~b}\end{array}$ & $1.29 \pm 0.01 \mathrm{~b}$ & $\begin{array}{c}57.10 \pm 0.3 \\
7 \mathrm{c} \\
\end{array}$ \\
\hline $4.5 \%$ & $\begin{array}{c}8.20 \pm 0.12 \\
a \\
\end{array}$ & $\begin{array}{c}190.11 \pm 1 \\
51 \mathrm{a}\end{array}$ & $\begin{array}{c}182.01 \pm 0.0 \\
1 \mathrm{a} \\
\end{array}$ & $\begin{array}{c}0.75 \pm 0.0 \\
3 \mathrm{a} \\
\end{array}$ & $1.31 \pm 0.01 \mathrm{a}$ & $\begin{array}{c}55.12 \pm 0.3 \\
7 \mathrm{~d}\end{array}$ \\
\hline \multicolumn{7}{|l|}{$\begin{array}{l}\text { Comm } \\
\text { on carp }\end{array}$} \\
\hline $1.5 \%$ & $\begin{array}{c}5.31 \pm 0.07 \\
\mathrm{a} \\
\end{array}$ & $\begin{array}{c}400.35 \pm 3 . \\
12 \mathrm{~d} \\
\end{array}$ & $\begin{array}{c}395.04 \pm 0.0 \\
6 \mathrm{~d} \\
\end{array}$ & $\begin{array}{c}1.64 \pm 0.0 \\
5 \mathrm{~d} \\
\end{array}$ & $1.80 \pm 0.02 \mathrm{~d}$ & $\begin{array}{c}82.13 \pm 0.2 \\
8 \mathrm{~d} \\
\end{array}$ \\
\hline $2.5 \%$ & $\begin{array}{c}5.00 \pm 0.07 \\
a\end{array}$ & $\begin{array}{c}450.12 \pm 3 . \\
12 \mathrm{c}\end{array}$ & $\begin{array}{c}444.81 \pm 0.0 \\
6 \text { c }\end{array}$ & $\begin{array}{c}1.85 \pm 0.0 \\
5 \mathrm{c}\end{array}$ & $1.84 \pm 0.02 \mathrm{c}$ & $\begin{array}{c}84.15 \pm 0.2 \\
8 c\end{array}$ \\
\hline $3.5 \%$ & $\begin{array}{c}5.10 \pm 0.07 \\
\mathrm{a} \\
\end{array}$ & $\begin{array}{c}480.42 \pm 3 \\
12 \mathrm{~b}\end{array}$ & $\begin{array}{c}475.42 \pm 0.0 \\
6 \mathrm{~b} \\
\end{array}$ & $\begin{array}{c}1.98 \pm 0.0 \\
5 \mathrm{~b} \\
\end{array}$ & $1.90 \pm 0.02 \mathrm{~b}$ & $\begin{array}{c}86.10 \pm 2.2 \\
8 \mathrm{~b} \\
\end{array}$ \\
\hline $4.5 \%$ & $\begin{array}{c}4.80 \pm 0.07 \\
\mathrm{a} \\
\end{array}$ & $\begin{array}{c}530.33 \pm 3 . \\
12 \mathrm{a} \\
\end{array}$ & $\begin{array}{c}525.23 \pm 0.0 \\
6 \mathrm{a} \\
\end{array}$ & $\begin{array}{c}2.18 \pm 0.0 \\
5 \mathrm{a} \\
\end{array}$ & $1.93 \pm 0.02 \mathrm{a}$ & $\begin{array}{c}88.33 \pm 0.2 \\
8 \mathrm{a} \\
\end{array}$ \\
\hline
\end{tabular}

Values are means \pm SE of two replications

Means within each column having different letters were significantly different $(\mathrm{p}<0.05)$ 
Table (2): least square means and standard error for the effect of feeding levels on feed conversion ratio (FCR) of tilapia , mullet and common carp in polyculture system.

\begin{tabular}{|c|c|c|c|}
\hline Treatments & Feed intake kg/feedan & $\begin{array}{c}\text { Total fish production } \\
\mathrm{kg} / \text { feedan }\end{array}$ & FCR \\
\hline $1.5 \%$ & 5346.02 & 3718.63 & 1.43 \\
$2.5 \%$ & 5591.62 & 3948.54 & 1.41 \\
$3.5 \%$ & 7259.32 & 4222.21 & 1.71 \\
$4.5 \%$ & 9049.25 & 4536.02 & 1.99 \\
\hline
\end{tabular}

Means with the same letter in the same column are not significantly different at $(\mathrm{p}>0.05)$.

Table (3). The effect of the experimental treatments on total fish production Kg./Feddan.

\begin{tabular}{|c|c|c|c|c|c|c|c|c|c|}
\hline \multirow{2}{*}{$\begin{array}{l}\text { Feedin } \\
\text { g levels }\end{array}$} & \multicolumn{2}{|c|}{ Tilapia } & \multicolumn{2}{|c|}{ Mullet } & \multicolumn{2}{|c|}{ Common Carp } & \multicolumn{2}{|c|}{ Total } & \multirow{2}{*}{$\begin{array}{c}\text { \% of the } \\
\text { smallest } \\
\text { value }\end{array}$} \\
\hline & $\begin{array}{c}\text { Kg./Pon } \\
\text { d }\end{array}$ & $\begin{array}{c}\text { Kg./feed } \\
\text { dan }\end{array}$ & $\begin{array}{c}\text { Kg./P } \\
\text { ond }\end{array}$ & $\begin{array}{l}\text { Kg./fe } \\
\text { eddan }\end{array}$ & $\begin{array}{c}\text { Kg./Pon } \\
\text { d }\end{array}$ & $\begin{array}{c}\text { Kg./feedd } \\
\text { an }\end{array}$ & $\begin{array}{c}\mathrm{Kg} . / \mathrm{Po} \\
\text { nd }\end{array}$ & $\begin{array}{c}\text { Kg./fee } \\
\text { ddan }\end{array}$ & \\
\hline \multirow[t]{2}{*}{$1.5 \%$} & 5355.56 & 2811.66 & 741.14 & 389.09 & 986.42 & 517.87 & 7083.12 & 3718.63 & $100 \%$ \\
\hline & \multicolumn{2}{|c|}{$75.61 \%$} & \multicolumn{2}{|c|}{$10.46 \%$} & \multicolumn{2}{|c|}{$13.93 \%$} & \multicolumn{2}{|c|}{$100 \%$} & \\
\hline \multirow[t]{2}{*}{$2.5 \%$} & 5569.51 & 2923.99 & 815.23 & 427.99 & 1136.32 & 596.56 & 7521.06 & 3948.54 & $106.18 \%$ \\
\hline & \multicolumn{2}{|c|}{$74.05 \%$} & \multicolumn{2}{|c|}{$10.84 \%$} & \multicolumn{2}{|c|}{$15.11 \%$} & \multicolumn{2}{|c|}{$100 \%$} & \\
\hline \multirow[t]{2}{*}{$3.5 \%$} & 5901.05 & 3098.05 & 900.50 & 472.76 & 1240.92 & 651.48 & 8042.47 & 4222.21 & $113.54 \%$ \\
\hline & \multicolumn{2}{|c|}{$73.37 \%$} & \multicolumn{2}{|c|}{$11.20 \%$} & \multicolumn{2}{|c|}{$15.43 \%$} & \multicolumn{2}{|c|}{$100 \%$} & \\
\hline \multirow[t]{2}{*}{$4.5 \%$} & 6291.64 & 3303.11 & 943.09 & 495.12 & 1405.32 & 737.79 & 8640.05 & 4536.02 & $121.98 \%$ \\
\hline & \multicolumn{2}{|c|}{$72.82 \%$} & \multicolumn{2}{|c|}{$10.91 \%$} & \multicolumn{2}{|c|}{$18.27 \%$} & \multicolumn{2}{|c|}{$100 \%$} & \\
\hline
\end{tabular}


Table (4).The effect of the experimental feeding levels on economic efficiency (Egyptian pound L.E / Feddan)

\begin{tabular}{|c|c|c|c|c|}
\hline \multirow[t]{2}{*}{ Items } & \multicolumn{4}{|c|}{ Treatments } \\
\hline & $1.5 \%$ & $2.5 \%$ & $3.5 \%$ & $4.5 \%$ \\
\hline \multicolumn{5}{|l|}{ 1- Costs L.E/fed. } \\
\hline \multicolumn{5}{|l|}{$\begin{array}{l}\text { a- Costs of fish } \\
\text { stocking }\end{array}$} \\
\hline N.tilapia & 3780 & 3780 & 3780 & 3780 \\
\hline Mullet & 2350 & 2350 & 2350 & 2350 \\
\hline Common carp & 47.10 & 47.10 & 47.10 & 47.10 \\
\hline b-Costs of feed & 9088.24 & 9505.77 & 12340.85 & 15383.74 \\
\hline $\begin{array}{l}\text { c-cost of } \\
\text { fertilization }\end{array}$ & 350 & 350 & 350 & 350 \\
\hline d-Labor & 500 & 500 & 500 & 500 \\
\hline $\begin{array}{l}\text { e- Others (Pumps } \\
\text {,solar,...et.) }\end{array}$ & 998 & 998 & 998 & 998 \\
\hline Total costs & 17113.34 & 17530.87 & 20365.95 & 23408.84 \\
\hline \multicolumn{5}{|l|}{ 2-Return } \\
\hline $\begin{array}{l}\text { a-Total fish } \\
\text { production } \\
\text { (Ton/fed.) }\end{array}$ & 3718.63 & 3948.54 & 4222.21 & 4536.02 \\
\hline b-Total income* & 26030.41 & 27639.78 & 29555.47 & 31752.14 \\
\hline $\begin{array}{l}\text { c-Net return } \\
\text { L.E/fed }\end{array}$ & 8927.07 & 10108.91 & 9189.52 & 8343.3 \\
\hline $\begin{array}{l}\text { \% of the } \\
\text { smallest value }\end{array}$ & $106.99 \%$ & $121.16 \%$ & $110.14 \%$ & $100 \%$ \\
\hline $\begin{array}{l}\text { \% Net returns } \\
\text { to total costs }\end{array}$ & $52.16 \%$ & $57.66 \%$ & $45.12 \%$ & $35.64 \%$ \\
\hline
\end{tabular}

*The economical evaluation of results was carried out according to market prices in 2005 in L.E. 